\title{
Crisis Management in Hotel Business - Insights from Croatia
}

Preliminary communication, _ DOI 10.22522/cmr20170225 _ received on 10 July 2017 UDK 005.334:640.4(497.5)

\section{Ivana Bilić}

Faculty of Economics, University of Split, Croatia. Email: ibilic@efst.hr (corresponding author)

\section{Smiljana Pivčević}

Faculty of Economics, University of Split, Croatia. Email: smiljana.pivcevic@efst.hr

\section{Ana Čevra}

Email: cevra.ana@gmail.com

\section{Abstract}

Owing to the numerous peculiarities of the hotel business, the sensitivity of this sector to crisis situations is higher compared to other economic sectors. International tourism and hospitality as crucial elements of the tourism offer are exposed to a number of crises and disasters. Therefore, the crisis management concept must play a significant role in the operations of tourism companies and this paper addresses this issue. It starts with theoretical framework reviewing the fundamental determinants of tourism, concepts of crisis and crisis management in international tourism and the importance of crisis management in the hotel business. In the empirical part of the paper, the results of a survey conducted on a sample of 59 hotels in the Split-Dalmatia County are presented with the aim of providing insights about their approach on handling crisis situations.

Keywords: hotel companies, crisis, crisis management, Split-Dalmatia County 


\section{Introduction}

Crisis management has become an important part of contemporary business; moreover, the knowledge and readiness of a company's management for a potential crisis plays a crucial role in the prevention and successful crisis management during and after a crisis occurs. The number of tourism related crises rapidly grew at the beginning of the $21^{\text {st }}$ century - according to Hall (2010) from 1977 to 2010, a total of 37 tourism crises occurred, 34 of them since 2000 . Motivated by the rapidly growing number of business crises, where some types of crises highly affected the tourism industry and hotel business, the level of hotels managers' knowledge about crisis management become increasingly important. Moreover, the awareness of hotel managers about the possible sources of crisis in the hotel industry and tourism, previous experience and success in overcoming past crises, and development of crisis plans and crisis manuals for hotels crisis teams has become extremely important. The main purpose of this paper is to explore the level of knowledge and readiness of Croatian hoteliers for crisis management. The research was conducted in the period between the huge wave of refugees from the East and the 2016 tourist season, when it was not clear what will happen next. At the time, the media and other relevant sources discussed greatly the potential negative effects that the immigration winter route across the Dalmatian coast could have on the upcoming 2016 season and the view and actions taken by hotel managers were not known.

\section{Crisis Management and Tourism}

Each business may be confronted with an internal and external crisis, and the most important part in successfully overcoming a crisis is the early detection of warning signs and readiness for the crisis. From that perspective, management readiness and knowledge may serve as a cushion in times of crisis. Manning (1999) saw risk management as a crucial factor for any sustainable tourism development. Camillo et al. (2015) clearly stated that the complexities of modern crises often require the involvement of many actors, except emergency services (detected as the most important source of crisis in our research), effective crisis communication, coordination and synergy among all parties involved to achieve a 
successful outcome. From another perspective, Croatia already faced the total devastation of its tourism industry during the Homeland Defence War, and it is expected that Croatian tourist managers and hoteliers will be aware of possible threats from the environment.

\subsection{Crisis Management}

A crisis is a major occurrence with a potentially negative outcome affecting the organization, company, or industry, as well as its publics, products, services, or good name (Fearn-Banks, 2011, p. 2). The Institute for Crisis Management (ICM, 2014) defined a business crisis as any issue, problem or disruption that triggers negative stakeholder reactions that impact the organization's business and financial strength. Furthermore, ICM identifies four potential crisis types: Sudden, Perceptual, Smouldering, and Bizarre. Regardless of origin, all crises possess several common characteristics (Argenti, 2009): (1) element of surprise, (2) insufficient information; and (3) quick pace of the event.

Pearson and Mitroff (1999) proposed a five stage framework for crisis management: 1) signal detection; 2) preparation/prevention; 3) containment/damage limitation; 4) recovery; and the most interesting last one 5) learning. In any disaster, all five pillars of crisis management are important, however, preparation and ability for damage limitation is crucial to prevent additional damage when a disaster occurs. Furthermore, Ritchie (2004) proposed a more "holistic" strategic approach to crisis management, formulated in three phases: 1) proactive pre-crisis planning, 2) strategy implementation; and 3) evaluation and feedback. Moreover, it is strongly recommended for any company to develop a written crisis manual, with assigned roles and duties in the event of a crisis, which should serve as a Bible. Rittichainuwat (2013) stressed the importance of the crisis management role in tourism marketing, where a written crisis management plan is positively perceived as management's commitment to protect their guests.

Crisis communication represents an important part of any crisis situation and, moreover, reflects all crisis management before, during and after a crisis. Crisis communication in itself could be defined as the ongoing process of creating shared meaning among and between groups, communities, individuals and agencies (Sellnow, Seeger, 2013, p. 13). 


\subsection{Crisis in Tourism}

Ritchie et al. (2013) defined tourism as an open system, which is affected by external events often beyond the control of individuals or destinations. Although the sources of tourism crises may vary and differ in terms of manifestation type, the comprehensive definition of tourism crisis offered by Sönmez et al. (1994, p. 22) is still accurate: "any occurrence which can threaten the normal operation and conduct of tourism related businesses; damage a tourist destination's overall reputation for safety, attractiveness and comfort by negatively affecting visitors' perceptions of that destination; and, in turn, cause a downturn in the local travel and tourism economy and interrupt the continuity of business operations for the local travel and tourism industry by the reduction in tourist arrivals and expenditures". Also, it is important to identify which types of knowledge are important prerequisites for being in charge of crisis management. In their research, Paraskevas et al. (2013) identified four types of "crisis specific knowledge": procedural, behavioural, third-party knowledge and 'learned ignorance' necessary for successful crisis management.

The tourism industry and hoteliers are confronted with all of the business-related crises faced by other businesses, but regarding to its specific aspects, the scope of possible crisis sources is even wider. Many potential crisis sources may affect the tourism industry and hoteliers such as: natural disasters (flood, earthquake, fire), technology (viruses, hackers), malevolence, management misdeeds, employees misdeeds, workplace violence, wordof-mouth (in face-to-face contact or on the Internet), bankruptcy or economic reasons, external environmental reasons, food, bad services, fake customer reviews. Any type of the previously mentioned crises may appear suddenly or may be in the form of a smouldering crisis, and may be generated from the inside or vice versa. Camillo et al. (2015) highlighted some interesting findings in their research, and reveal no evidence in the standardization of risk prevention, risk and crisis management and a clear communication policy within the top 10 global hotels.

Ritchie et al. (2013) have noted that, in recent years, tourism has globally faced many crises, such as terrorist attacks, global political instability, economic recession, biosecurity, and other common crises such as natural disasters. Mikulić et al. (2016) identified 11 short term 
risks for Croatian tourism: 1) bad weather; 2) natural disasters; 3) disease outbreaks and epidemics; 4) terrorist attack; 5) political and societal instability in the region; 6) ecological incidents; 7) bad tourist experience; 8) generating market purchasing power; 9) exchange rate; 10) fuel price; and 11) more difficult border crossings. Also, same authors stressed that 7) bad tourist experience; 4) terrorist attack; and 1) bad weather represent risks that are more likely to occur. Furthermore, Paraskevas and Altinay (2013) have noted that the vulnerability of the tourism industry to a range of crises has been in the focus of many scholars from the perspective of crisis strategy and practices employed by destinations and tourism organizations, mostly with the focus on the preparedness for the crisis.

With a great appreciation to the previous research, particularly directed to Croatian tourism, the aim of our research does not overlap with them, as it is directed to hotel managers and their capacity for successful planning and overcoming crisis situations.

\subsection{Crisis Communication in Hotel Industry}

Although being an important factor of a hotel's operations, the academic literature has not given adequate attention to the topic of crisis communication in the hotel industry. A search of the term "Crisis communication in hotel industry" in Google scholar, the main database for academic papers, yields 189,000 results. This gives a great first impression that researchers see crisis and crisis communication as an integral part of the hotel business. However, a deeper look into the literature listed reveals that the articles are in fact not related specifically to crisis communication, but are focusing on the wider topic of crisis management in the hotel industry and tourism. Still, these studies also provide some interesting insights. Kim et al. (2005) study the post SARS crisis phase of learning in the Korean hotel industry, and find as important the establishment of effective channels of internal and external communication and an emergency communication network. Herrero (1999) argues of the importance of a developed communication plan in the tourism industry, with the purpose of managing and reducing the negative impact of crisis situations, which is also stressed in the work of Soñmez et al. (1999). Attempting to further validate the literature search, a second Google scholar search was run related to communication in the industry 
in general. Specifically, the term "hospitality management communication" was searched yielding 611.000 results. These were found to be mostly related to event organization or communication skills and to our best efforts, none focusing on crisis communication in hotels were found. To conclude, although academic studies on crisis communication in the tourism and hospitality industry are important and worthwhile, especially from the practical perspective, the conducted Google scholar based searches have made it more than obvious that, so far, it has not developed as a separate discipline, but is still observed only as a part of management and crisis management.

\section{Empiricall Research}

\subsection{Methodology}

Camillo et al. (2015) emphasized the interdependency within a crisis situation and crisis communication, established in advance by responsible managers, where synergy and interdependency in strategic crisis planning - crisis prevention both, pre- and post-crisis management is crucial. Furthermore, all participants in Paraskevas and Altinay's (2013) survey agreed that signal detection should be at the centre of any crisis management efforts in the organization and should become its first line of defence.

Tourism is one of the most economically important industries, particularly in the case of Croatia, with an impact of $18.9 \%$ on Croatia's GDP (Croatian Ministry of Tourism, 2017). In order to reveal the practice and features of hotel crisis management, an exploratory empirical research was conducted. The object of the study was Split-Dalmatia County (SDC), Croatia. SDC is one of the leading tourism regions in Croatia, receiving $17.2 \%$ of country's tourist arrivals, $18.6 \%$ of overnights and $20.6 \%$ of hotel numbers in 2015 (Ministry of Tourism, 2016). The study was conducted through a specifically designed questionnaire sent to the email addresses of all hotels in SDC which, at the time, were operating for more than 2 years. The mailing list included $126^{1}$ hotels and the surveying lasted from January till March 2016. Since the questions refer to the areas that are the responsibility of managers, the email

1 Out of 134 operating at that moment, according to the List of Categorized Hotels by the Ministry of Tourism, available at http:// www.mint.hr/default.aspx?ID=2505 
specified that the survey must be answered by the upper management level staff. In the end, 59 correctly completed questionnaires were received, achieving a $47 \%$ response rate.

The questionnaire consisted of 2 parts. The first included questions about crisis management practice and mostly consisted of 5 point Likert scale type questions formulated using adequate scale descriptions (Vagias, 2006). The second part of the questionnaire included questions about hotel and hotel manager characteristics.

\subsection{Hypotheses}

Deriving from the theoretical underpinnings presented above and owing to the exploratory nature of the empirical study, the following hypotheses were formulated:

H1: Managers perceive that they play a key role in ensuring the security protocols/procedures for crisis situations.

H2: The practice of employee training on handling crisis situations is well developed.

H3: The protocols and procedures for crisis situations are well developed.

H4: Compared to independent hotels, hotels in chains are better prepared for potential crisis situations.

H5: The probability of incidents and crisis events in hotels increases with the business volume and hotel size. 


\subsection{Results}

The respondent and hotel profiles are provided in Table 1.

Table 1. Characteristics of the sample

\begin{tabular}{|c|c|c|c|c|}
\hline \multirow{12}{*}{ 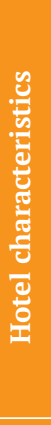 } & \multirow{4}{*}{ Hotel category } & $2 *$ & 1 & 1.7 \\
\hline & & $3 *$ & 24 & 40.7 \\
\hline & & $4^{*}$ & 33 & 55.9 \\
\hline & & $5 *$ & 1 & 1.7 \\
\hline & \multirow{3}{*}{ Years in business } & Less than 5 years & 11 & 18.6 \\
\hline & & $5-10$ years & 21 & 35.6 \\
\hline & & More than 10 years & 27 & 45.8 \\
\hline & \multirow{3}{*}{$\begin{array}{l}\text { Number of } \\
\text { accommodation units }\end{array}$} & Up to 50 & 34 & 57.6 \\
\hline & & $51-200$ & 21 & 35.6 \\
\hline & & More than 200 & 4 & 6.8 \\
\hline & \multirow{2}{*}{ Type of business } & Independent & 48 & 81.4 \\
\hline & & Hotel chain & 11 & 18.6 \\
\hline \multirow{17}{*}{ 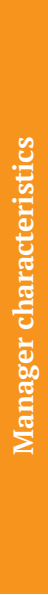 } & \multirow{3}{*}{ Management level } & Top management & 28 & 47.5 \\
\hline & & Middle management & 28 & 47.5 \\
\hline & & Lower management & 3 & 5.1 \\
\hline & \multirow{4}{*}{$\begin{array}{l}\text { Years of experience } \\
\text { in hotel business }\end{array}$} & Up to 1 & 3 & 5.1 \\
\hline & & $1-5$ & 7 & 11.9 \\
\hline & & $5-10$ & 24 & 40.7 \\
\hline & & 10 or more & 25 & 42.4 \\
\hline & \multirow{4}{*}{$\begin{array}{l}\text { Years of experience } \\
\text { in current position }\end{array}$} & Up to 1 & 5 & 8.5 \\
\hline & & $1-5$ & 22 & 37.3 \\
\hline & & $5-10$ & 21 & 35.6 \\
\hline & & 10 or more & 11 & 18.6 \\
\hline & \multirow{2}{*}{ Sex } & Male & 23 & 39.0 \\
\hline & & Female & 36 & 61.0 \\
\hline & \multirow{4}{*}{ Age } & $20-30$ & 16 & 27.1 \\
\hline & & $31-40$ & 23 & 39.0 \\
\hline & & $41-50$ & 13 & 22.0 \\
\hline & & More than 50 & 7 & 11.9 \\
\hline
\end{tabular}

Most of the hotels in the sample are $4 *$ hotels, operating for more than 10 years, with up to 50 accommodation units, and operating independently. As per the respondents, most are in top and middle management positions, with more than 10 years of experience in the hotel business and with up to 5 years of experience in the current position. Thus, they are relevant and competent to give opinions on this issue. Furthermore, most respondents are women aged 31-40. 
To gain insight on the most frequent crisis situations managers have encountered in the hotel business, a multiple choice question was asked (Figure 1). The results reveal the most frequent crisis situations are medical emergency (30.6\%), lost luggage (20.7\%) and guest complaints (18.9\%), while the rarest ones are food poisoning (1.8\%) and crime (4.5\%).

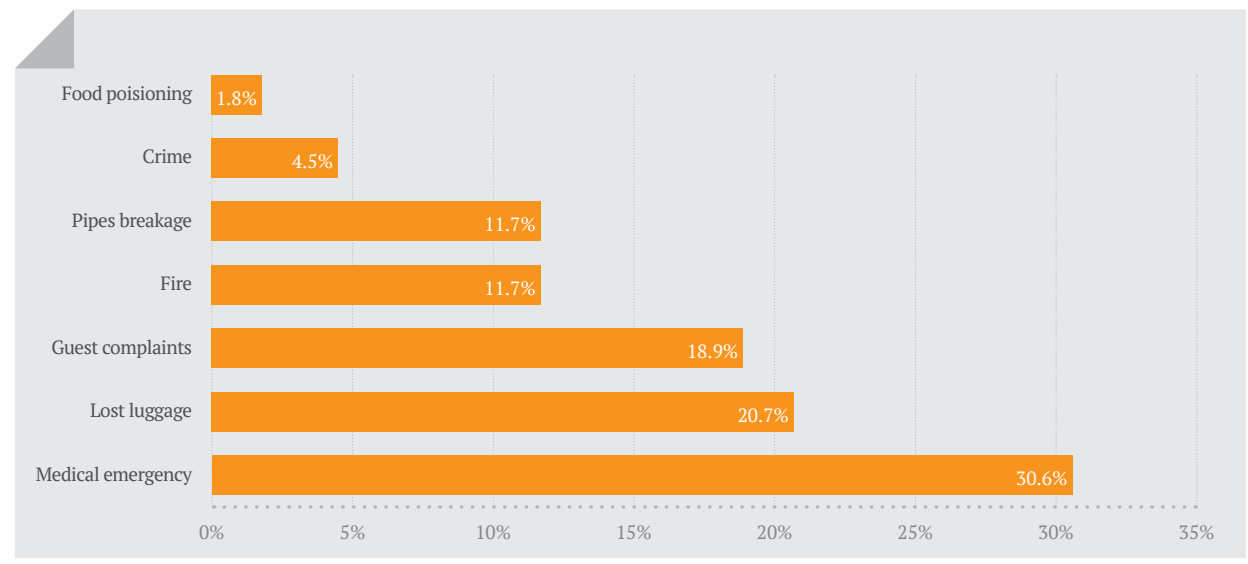

Figure 1. Types of crisis situations encountered in hotels

On the other hand, a look at the frequency of crisis situations in the last 10 years (Figure 2) reveals these are, in fact, not frequently encountered.

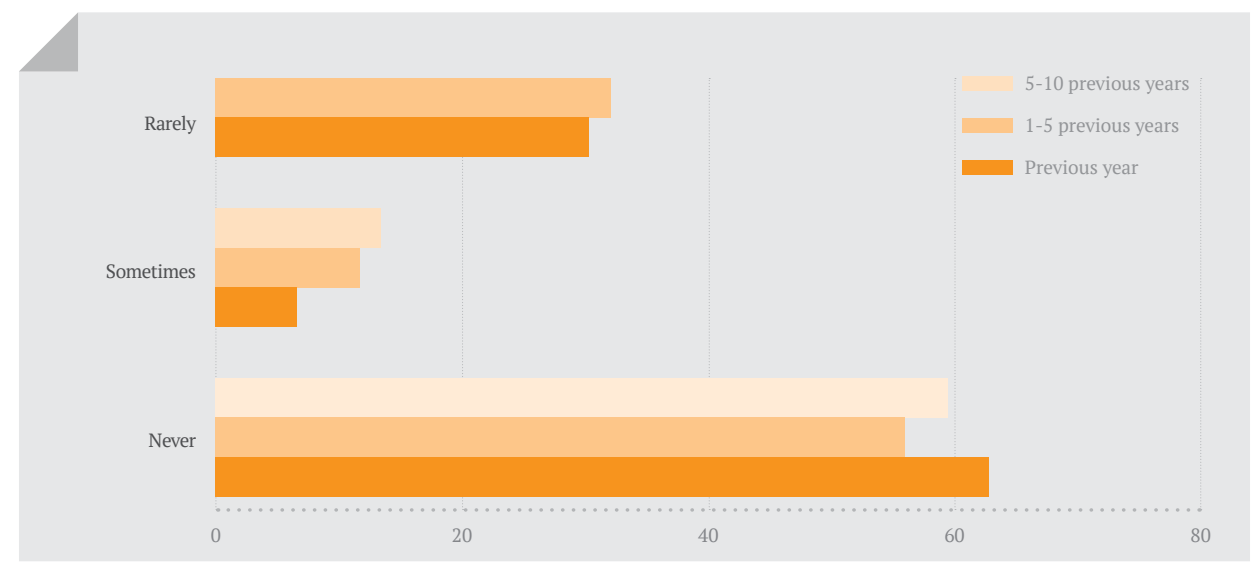

Figure 2. Frequency of crisis situations in previous period 
In order to explore the influences of global issues/challenges upon hotel manager decision making, a question about these was asked and the descriptive statistics of answers is given in Table 2.

Table 2. The influence of global issues on hotel manager decisions and activities

\begin{tabular}{|c|c|c|c|c|c|c|}
\hline & No effect & $\begin{array}{l}\text { Minor } \\
\text { effect }\end{array}$ & Neutral & $\begin{array}{l}\text { Moderate } \\
\text { effect }\end{array}$ & $\begin{array}{l}\text { Major } \\
\text { effect }\end{array}$ & Total \\
\hline $\begin{array}{l}\text { Global tourism } \\
\text { market and overall } \\
\text { trends and events }\end{array}$ & 1.7 & 3.4 & 20.3 & 54.2 & 20.3 & 100.0 \\
\hline The refugee crisis & 10.2 & 25.4 & 35.6 & 23.7 & 5.1 & 100.0 \\
\hline $\begin{array}{l}\text { The safety of } \\
\text { guests in hotels }\end{array}$ & 8.5 & 3.4 & 32.2 & 22.0 & 33.9 & 100.0 \\
\hline $\begin{array}{l}\text { Potential threats } \\
\text { and terrorist } \\
\text { attacks in the } \\
\text { destination }\end{array}$ & 20.3 & 16.9 & 32.2 & 16.9 & 13.6 & 100.0 \\
\hline
\end{tabular}

As the analysis shows, from the factors listed, managers find the "Global tourism market and overall trends" as most influential for their decisions and actions (74.5\% perceive it to have a moderate or major effect). The second most important is "Safety of guests in hotels" (moderate or major effect for 55.9\%). On the other hand, the least important factor from this perspective are "Potential threats and terrorist attacks in the destination", with less than one third of respondents finding it to have effect on their decisions/activities. This demonstrates the high level of destination security perceived by tourism businesses.

Table 3 provides descriptions of manager opinions about different aspects of crisis management in general. These data shows that managers realize the importance of all the four aspects listed since the most frequent answer to all of them is "I agree" (coded as 4). 
Table 3. Descriptive statistics of managers's opinions about crisis management in general

\begin{tabular}{|c|c|c|c|c|c|c|}
\hline & \multicolumn{2}{|c|}{$\mathbf{N}$} & \multirow{2}{*}{ Mean } & \multirow{2}{*}{ Median } & \multirow{2}{*}{ Mode } & \multirow{2}{*}{$\begin{array}{c}\text { Std. } \\
\text { Deviation }\end{array}$} \\
\hline & Valid & Missing & & & & \\
\hline $\begin{array}{l}\text { Managers play a key role } \\
\text { in the organization and } \\
\text { implementation of plans, } \\
\text { procedures and protocols } \\
\text { for handling crisis situations }\end{array}$ & 59 & 0 & 4.220 & 4.000 & 4.0 & .6965 \\
\hline $\begin{array}{l}\text { Investing in safety must } \\
\text { not be seen as a cost, but } \\
\text { as an investment ensuring } \\
\text { competitive hotel business }\end{array}$ & 59 & 0 & 4.051 & 4.000 & 4.0 & .8987 \\
\hline $\begin{array}{l}\text { Due to often direct guest } \\
\text { contact, it is important for } \\
\text { each hotel employee to be } \\
\text { trained for handling crisis } \\
\text { situations }\end{array}$ & 59 & 0 & 4.339 & 4.000 & 4.0 & .7098 \\
\hline $\begin{array}{l}\text { The organization and } \\
\text { implementation of a well- } \\
\text { developed security system } \\
\text { by management diminishes } \\
\text { the risk of crisis situations. }\end{array}$ & 59 & 0 & 4.068 & 4.000 & 4.0 & .8683 \\
\hline
\end{tabular}

However, when it comes to the crisis management procedures and activities implemented in the hotels they manage, the results are much different. Namely, the highest rated element ("I am acquainted with developments in the global tourism market and in the world in general") has an average agreement of 3.644 (just slight agreement) and mode "I agree". All other elements have an even lower result, showing that these elements are not well developed in hotel practice. The lowest agreement (2.305 with median option being "I disagree") is found for the statement "We have developed plans and procedures for potential crisis situations". This is far from the recommended strategy since crises are unpredictable and sudden by their nature, but can much more efficiently be dealt with if the organization (hotel) is prepared. 
Table 4. Descriptive statistics of manager responses/attitudes

\begin{tabular}{|c|c|c|c|c|c|c|}
\hline & \multicolumn{2}{|c|}{$\mathbf{N}$} & \multirow{2}{*}{ Mean } & \multirow{2}{*}{ Median } & \multirow{2}{*}{ Mode } & \multirow{2}{*}{$\begin{array}{l}\text { Std. } \\
\text { Deviation }\end{array}$} \\
\hline & Valid & Missing & & & & \\
\hline $\begin{array}{l}\text { I am acquainted with } \\
\text { developments in the global } \\
\text { tourism market and in the } \\
\text { world in general }\end{array}$ & 59 & 0 & 3.644 & 4.000 & 4.0 & 1.1259 \\
\hline $\begin{array}{l}\text { The staff in my hotel is } \\
\text { trained for handling crisis } \\
\text { situations }\end{array}$ & 59 & 0 & 3.102 & 3.000 & 3.0 & 1.0938 \\
\hline $\begin{array}{l}\text { We have developed plans } \\
\text { and procedures for potential } \\
\text { crisis situations }\end{array}$ & 59 & 0 & 2.305 & 2.000 & 1.0 & 1.1782 \\
\hline $\begin{array}{l}\text { The hotel has a database } \\
\text { with potential crisis } \\
\text { situations }\end{array}$ & 59 & 0 & 2.525 & 3.000 & 3.0 & 1.0884 \\
\hline $\begin{array}{l}\text { Crisis team(s) for potential } \\
\text { crisis situations is/are } \\
\text { defined }\end{array}$ & 59 & 0 & 2.407 & 2.000 & 1.0 & 1.2194 \\
\hline $\begin{array}{l}\text { The spokespersons in a } \\
\text { potential crisis are defined } \\
\text { and known }\end{array}$ & 59 & 0 & 3.390 & 4.000 & $4.0^{\mathrm{a}}$ & 1.3264 \\
\hline $\begin{array}{l}\text { Media teams for crisis } \\
\text { situations are prepared }\end{array}$ & 59 & 0 & 2.085 & 2.000 & 1.0 & 1.1490 \\
\hline $\begin{array}{l}\text { Top management } \\
\text { is educated for } \\
\text { communicating with media } \\
\text { in crisis situations. }\end{array}$ & 59 & 0 & 2.864 & 3.000 & 3.0 & 1.4198 \\
\hline $\begin{array}{l}\text { Crisis teams are informed } \\
\text { about their duties and } \\
\text { responsibilities in case of } \\
\text { a crisis }\end{array}$ & 59 & 0 & 2.915 & 3.000 & 3.0 & 1.2904 \\
\hline $\begin{array}{l}\text { An detailed crisis } \\
\text { management manual is in } \\
\text { place }\end{array}$ & 59 & 0 & 2.593 & 2.000 & 2.0 & 1.1614 \\
\hline
\end{tabular}

According to the results presented in Table 4, there is an evident lack of readiness of Croatian tourism managers and hoteliers for a crisis situation, with an average score mostly below 3. Particularly when we take into account the perception of a potential crisis situation they identified before such as lost luggage and emergency care. It is also important to report an incredibly low level of development of crisis plans or procedures with a mean of 2.305, or for defined crisis teams, 2.407 . 


\subsection{Hypothesis Testing}

For testing the hypotheses $\mathrm{H1}-\mathrm{H3}$, a one sample Student's t-test was performed. It determines if there is sufficient evidence to conclude that the mean of the population from which the sample is taken is different from the specified value i.e. test value (Lane et al., $\mathrm{n} / \mathrm{a}$ ). The results of hypothesis testing are given in Table 5.

Table 5. One sample T-test results for $\mathrm{H} 1, \mathrm{H} 2$ and $\mathrm{H} 3$

\section{(Test Value $=3.5)$}

\begin{tabular}{|c|c|c|c|c|c|c|c|c|c|}
\hline \multirow{2}{*}{$\begin{array}{l}\frac{n}{3} \\
\frac{0}{0} \\
\frac{0}{0} \\
\frac{2}{2}\end{array}$} & \multirow{2}{*}{ 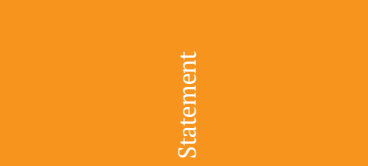 } & \multirow{2}{*}{$\sum_{\Sigma}^{\varpi}$} & \multirow[b]{2}{*}{$H$} & \multirow[b]{2}{*}{ tᄂ } & \multirow{2}{*}{ 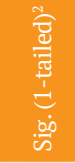 } & \multirow{2}{*}{ 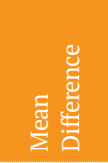 } & \multicolumn{2}{|c|}{$\begin{array}{l}95 \% \text { Confidence } \\
\text { Interval of the } \\
\text { Difference }\end{array}$} & \multirow{2}{*}{ 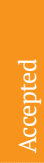 } \\
\hline & & & & & & & Lower & Upper & \\
\hline H1 & $\begin{array}{l}\text { Managers play a key role in the } \\
\text { organization and implementation } \\
\text { of plans, procedures and protocols } \\
\text { for handling crisis situations }\end{array}$ & 4.220 & 7.944 & 58 & .000 & .7203 & .539 & .902 & + \\
\hline H2 & $\begin{array}{l}\text { The staff in my hotel is trained to } \\
\text { handle crisis situations }\end{array}$ & 3.102 & 2.797 & 58 & .003 & -.3983 & -.683 & -.113 & - \\
\hline \multirow{8}{*}{ H3 } & $\begin{array}{l}\text { We have developed plans and } \\
\text { procedures for potential crisis } \\
\text { situations }\end{array}$ & 2.305 & 7.790 & 58 & .000 & -1.1949 & -1.502 & -.888 & - \\
\hline & $\begin{array}{l}\text { The hotel has a database with } \\
\text { potential crisis situations }\end{array}$ & 2.525 & 6.878 & 58 & .000 & -.9746 & -1.258 & -.691 & - \\
\hline & $\begin{array}{l}\text { Crisis team(s) for potential crisis } \\
\text { situations is/are defined }\end{array}$ & 2.407 & 6.887 & 58 & .000 & -1.0932 & -1.411 & -.775 & - \\
\hline & $\begin{array}{l}\text { The spokespersons in potential } \\
\text { crisis are defined and known }\end{array}$ & 3.390 & .638 & 58 & .263 & -.1102 & -.456 & .235 & - \\
\hline & $\begin{array}{l}\text { Media teams for crisis situations } \\
\text { are prepared }\end{array}$ & 2.085 & 9.461 & 58 & .000 & -1.4153 & -1.715 & -1.116 & - \\
\hline & $\begin{array}{l}\text { Top management is educated for } \\
\text { communicating with media in } \\
\text { crisis situations }\end{array}$ & 2.864 & 3.439 & 58 & .001 & -.6356 & -1.006 & -.266 & - \\
\hline & $\begin{array}{l}\text { Crisis teams are informed about } \\
\text { their duties and responsibilities in } \\
\text { case of crisis }\end{array}$ & 2.915 & 3.481 & 58 & .001 & -.5847 & -.921 & -.248 & - \\
\hline & $\begin{array}{l}\text { An elaborated crisis management } \\
\text { manual is in place }\end{array}$ & 2.593 & 5.997 & 58 & .000 & -.9068 & -1.209 & -.604 & - \\
\hline
\end{tabular}

2 Since testing on lower threshold is applied, a one-tailed test is appropriate (Lane et al., n/a) 
The results show that $\mathrm{H} 1$ has been confirmed, while $\mathrm{H} 2$ and $\mathrm{H} 3$ are to be rejected. In other words, hotel managers perceive they play a key role in the development and implementation of protocols and procedures in crisis management, but employees are not adequately trained for them nor are adequate activities and protocols developed.

For testing H4, the Mann Whitney test was used. The results (Table 6) show that there is no statistically significant difference in the preparation for crisis situations between the two types of hotel businesses so $\mathrm{H} 4$ is to be rejected.

Table 6. Mann Whitney test for difference in preparation for crisis management between independent and chain hotels

\begin{tabular}{|c|c|c|c|c|c|}
\hline & $\begin{array}{l}\text { We have } \\
\text { developed } \\
\text { plans and } \\
\text { procedures for } \\
\text { potential crisis } \\
\text { situations }\end{array}$ & $\begin{array}{c}\text { The hotel has } \\
\text { a contingency } \\
\text { plan for fire }\end{array}$ & $\begin{array}{c}\text { The hotel has } \\
\text { a contingency } \\
\text { plan for } \\
\text { earthquake }\end{array}$ & $\begin{array}{c}\text { The hotel has } \\
\text { a contingency } \\
\text { plan for } \\
\text { epidemic }\end{array}$ & $\begin{array}{c}\text { The hotel has } \\
\text { a contingency } \\
\text { plan for a } \\
\text { terrorist attack }\end{array}$ \\
\hline $\begin{array}{l}\text { Mann- } \\
\text { Whitney U }\end{array}$ & 118.000 & 165.000 & 183.500 & 123.000 & 156.500 \\
\hline Wilcoxon W & 1393.000 & 1440.000 & 1458.500 & 1398.000 & 1431.500 \\
\hline $\mathrm{Z}$ & -1.919 & -.877 & -.384 & -1.781 & -1.015 \\
\hline $\begin{array}{l}\text { Asymp. Sig. } \\
\text { (2-tailed) }\end{array}$ & .055 & .380 & .701 & .075 & .310 \\
\hline $\begin{array}{l}\text { Exact Sig. } \\
{[2 *(1 \text {-tailed }} \\
\text { Sig. })]\end{array}$ & $.065^{b}$ & $.444^{\mathrm{b}}$ & $.715^{\mathrm{b}}$ & $.085^{b}$ & $.333^{b}$ \\
\hline
\end{tabular}

Finally, for testing H5, the Kruskal-Wallis test was used combining the question on hotel size (defined as an ordinal scale with three levels) and frequency of crisis situations in previous periods (Figure 2). The results (Table 7) reveal that there is no statistically significant difference in frequency of crisis situations among hotels of different size. Thus, $\mathrm{H} 4$ is to be rejected as well. 
Table 7. Kruskal-Wallis test for frequency of crisis situation according to hotel size

\section{Previous year}

Chi-Square

Df

Asymp. Sig.
5.259

2

.072

\section{1-5 previous years}

4.927

2

.085
5-10 previous years

5.150

2

.076

a. Kruskal-Wallis Test

b. Grouping Variable: Number of accommodation units

\section{Discussion}

The results of the explorative study conducted reveal interesting and new insights about an important hotel business aspect which is not researched often in Croatia (Ivandić, 2016). A positive finding is that crisis situations are not often encountered in the hotel business in the surveyed area. On the other hand, the study revealed that, although hotel managers perceive that they play a key role in the preparation for crisis situations, none of the activities from this domain are adequately developed (employee training, database of crisis situations, plans/protocols, crisis teams, media teams, training of top management for communication with media, crisis management manual). In fact, only one activity is moderately developed - defined spokesperson for crisis situations (average 3.39; mode 4).

The potential reason for this poor result could be the not so high occurrence of crisis situations (Figure 1 and 2). In order words, the low frequency of crisis situations has made hotel managers feel somewhat "relaxed" about this issue and/or other business priorities have prevailed. Besides the low level of crisis situations, the perceived destination safety (Table 2) probably also contributes to the inadequate preparation for crisis situations, as Croatia is generally perceived as a safe destination. This, of course, is not an adequate strategy, to the contrary - it can have devastating consequences in case crises do strike. Having in mind the frequency and diversity of crisis situations encountered globally in recent years, a logical recommendation for hotel practice is to start working on these aspects immediately. Furthermore, since hotels are in most cases tourism industry pioneers in most aspects of business activities, one can presume that the preparation for crisis situations in other tourism industry segments is even lower. For this reason, a recommendation for 
relevant regulatory bodies is to investigate the level of preparation in the industry for crisis situations and to introduce adequate training and implementation activities.

A somewhat unexpected finding is that hotels operating in hotel chains are not better prepared for crisis situations than those operating independently. Namely, as operating in a standardized and organized system is one of the key features of hotel chain businesses, it was expected that such standardization would be found also in this domain, however, the findings did not support this. The same goes for the relationship between hotel size and crisis frequency - although it was expected that the relationship would be positive, no evidence to support that stance was found. However, this finding needs to be viewed in light of the overall low frequency of crisis situations found.

\section{Conclusion}

The hotel management process is extremely complex, mostly because of the services, which can include many different operations organized in house, or through outsourcing. On the other hand, as any other business, the hotel business is vulnerable as it is exposed to internal and external influences. These need to be anticipated, and crisis management needs to be in place for them. In such complex conditions, hoteliers are required to be more entrepreneurially oriented, more imaginative, penetrative, persistent, and patient in order to meet the needs of global tourists from all generations. The characteristics of hotel services, the organizational structure of the hotel, the role of human resources, the importance of standards and the specifics of maintaining a hotel company are the most important aspects that every manager must pay special attention to.

Today, tourism faces numerous crisis situations that create problems in the business of tourist destinations and hotel organizations. The underlying problem that arises is not only the fact that most of these events cannot be foreseen, but also ignorance of newly emerging situations as a result of lack of knowledge about crisis management or knowledge about crisis situations management. Due to the intensified emergence of various types of crises and disasters in modern society, the only way to mitigate their negative impact is the implementation of strategic crisis management in companies. Although crisis management readiness and knowledge will not eliminate or completely prevent a crisis if it occurs, it can 
be of great assistance in controlling the damage of the crisis. As the specific nature of the hotel business makes hotel companies more vulnerable to the impact of crisis situations compared to other companies, it is apparent that even smaller incidents in hotels can cause a decline in tourist demand. All this leads to the conclusion that hotel managers must pay great attention to studying potential crisis situations in hotels and the tourism industry, and prepare potential scenarios in case of their appearance. Furthermore, it is recommended to act in advance and prepare all preventive activities related to the organization of hotel security, emergency response procedures, employee safety training and the formation of crisis management teams. Henderson (2007) stressed the interdependencies between a crisis in the tourism sector and its repercussions in other sectors. Therefore, these findings may help practitioners embarking in the design of crisis management protocols and plans in tourism and hospitality industry, as a basic framework for all who have a chance to establish, maintain and train hotel management and other staff in tourism to be better prepared to recognize the first warning signals, prevent or ease a crisis.

The empirical part of the paper was based on the study of 59 hotels in the Split-Dalmatia County, Croatia. Due to the scarce insights on the subject matter, an exploratory study was performed. The results have revealed that the overall occurrence of crisis situations in the examined hotels was low, however, unfortunately, so is their level of preparation for diverse crisis situations. The managers believe that they play the key role in ensuring these activities, nevertheless, all of the activities listed are poorly developed. Nevertheless, the results did not demonstrate a statistically significant difference in crisis situation frequency according to hotel size or in the preparation for crisis situations between independent hotels and those belonging to hotel chains. Thus, $\mathrm{H} 1$ was confirmed, while hypotheses $\mathrm{H} 2$ - H5 were rejected. In interpreting the results, the limitations of the study need to be taken into account. These are related to the limited geographical area covered (1 county), sample size, limited scope of questions/aspects covered in the questionnaire and general limitation of respondent subjectivity. It is suggested that these should be dealt with in future studies on the subject. 


\section{Reference List}

- Camillo, A. A. et al. (2015). A Global Perspective on the Strategic Enterprise Risk Management and Crisis Preparedness. XXVII Convegno annuale di Sinergie, Heritage, management e impresa: quali sinergie?, 9-10 luglio 2015 - Università degli Studi del Molise-sede di Termoli, Referred Electronic Conference Proceeding.

- Fearn-Banks, K. (2011). Crisis Communications: a casebook approach (4 ${ }^{\text {th }}$ edition). New York: Routledge.

- Hall, C. M. (2010). Crisis events in tourism: subjects of crisis in tourism. Current Issues in Tourism, 13 (5), 401 -417.

- Henderson, J. C. (2007). Tourism crises: causes, consequences and management. Oxford: Butterworth-Heinmenann.

- Herrero, A. G. (1999). Product commercialization and crisis planning in the tourist sector: Corporative image and consumercentred marketing. Papers de Turisme, 24, 6 .

- Ivandic, N. (2016). Primjena kriznog menadžmenta u hotelskoj industriji (graduate paper). Split: Ekonomski fakultet Sveučilišta u Splitu.

- Kim, S. S., Chung, H., Lee, H. (2005). The effects of SARS on the Korean hotel industry and measures to overcome the crisis: A case study of six Korean five-star hotels. Asia Pacific Journal of Tourism Research, 10 (4), 369-377.

- Lane, D. M., Scott, D., Hebl, M., Guerra, R., Osherson, D., Zimmer, H. (n.d.). Introduction to Statistics - Online Edition. Rice University, University of Houston Clear Lake, and Tufts University. Retrieved from: http://onlinestatbook.com/. 15 June 2017.

- Manning, T. (1999). Indicators of tourism sustainability. Tourism Management, 20, 179-182.

- Mikulić, J. et al. (2016). Strategic crisis management in tourism: An application of integrated risk management principles to the Croatian. Journal of Destination Marketing \& Management - in press. http://dx.doi.org/10.1016/j.jdmm.2016.08.001i.

- Paraskevas, A., Altinay, L. (2013). Signal detection as the first line of defence in tourism crisis management. Tourism Management, 34, 158-171.

- Paraskevas, A. et al. (2013). Crisis Knowledge in Tourism: Types, Flows and Governance. Annals of Tourism Research, 41, 130 -152.

- Pearson, C., Mitroff, I. (1999). From crisis prone to crisis prepared: A framework for crisis management. Academy of Management Executive, 7 (1), 48-59.

- Ritchie, B. W. et al. (2013). Understanding the Effects of a Tourism Crisis: The Impact of the BP Oil Spill on Regional Lodging Demand. Journal of Travel Research, 53 (1), 12-25.

- Ritchie, B. W. (2004). Chaos, crises and disasters: a strategic approach to crisis management in the tourism industry. Tourism Management, 25 (6), 669-683.

- Rittichainuwat, B. R. (2013). Tourists' and tourism suppliers' perceptions toward crisis management on tsunami. Tourism Management, 34, 112-121.

- Sellnow, T. L., Seeger, M. W. (2013). Theorizing Crisis Communication. West Sussex, UK: John Wiley \& Sons Ltd.

- Soñmez, S. F., Apostolopoulos, Y., Tarlow, P. (1999). Tourism in crisis: Managing the effects of terrorism. Journal of Travel Research, 38 (1), 3-18.

- Sonmez, S. F., Backman, S. J., Allen, L. R. (1994). Managing tourism crises: A guidebook. Clemson, SC: Clemson University.

- Vagias, W. M. (2006). Likert-type scale response anchors. Clemson International Institute for Tourism \& Research Development, Department of Parks. Recreation and Tourism Management. Clemson University.

\section{Internet Sources}

- Ministry of tourism of Croatia (2015). Tourism in numbers in 2015. Retrieved from: http://www.mint.hr/default.aspx?id=39211. 15 June 2017. 


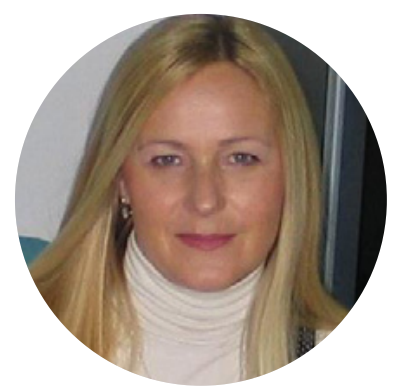

Ivana Bilić

Ivana Bilić is an Assistant Professor at the Department of Management of Faculty of Economics, University of Split. Her main scientific interests are communication, management and crisis management, and entrepreneurship. In scientific area she has published four book chapters and around 25 articles in international peer-reviewed journals or international scientific conference. She has worked on a number of national and international scientific projects. For her work she has been awarded from many organizations and institutions such as: ZIP - Zagreb Entrepreneurship Incubator, Shift Conference, Crowdfunding Academy, US Embassy Zagreb, US Department of State and her home institution Faculty of Economics.

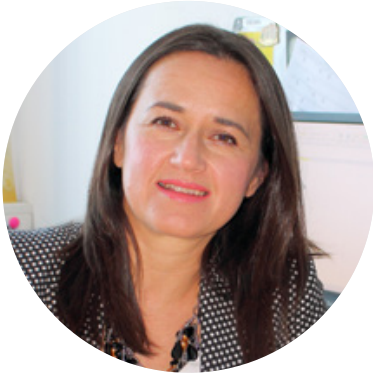

Smiljana Pivčević

Smiljana Pivčević is an Associate Professor of Tourism and Head of Department of Tourism and Economy at Faculty of Economics, University of Split. Her main scientific interests are innovation in tourism and hospitality, tourism development and special interest tourism. She has published two book chapters and more than 20 papers in international peer-reviewed journals and conference proceedings. She has worked as an expert and project leader on regional and local projects as well as international EU funded projects in the area of tourism. Her expert work has been awarded by Split-Dalmatia County, University of Split and her home institution Faculty of Economics.

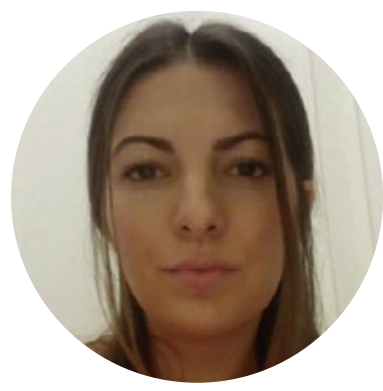

Ana Čevra

Ana Čevra is an Tourism Intern at Memento Travel Agency in Split. She gratuated from the Faculty of Economics, University of Split with master degree in Tourism and Hospitality in 2016. Her master thesis, under the mentorship of dr. Ivana Bilic was "Crisis management in hotel business". During her education she has gained valuable skills and knowledge in the various areas such as Tourism Management, Marketing Research in Tourism, Strategic Management of the Hotel, Hotel Accounting, Crisis Management and Event Management. Her scientific interests are hotel business, crisis management and historic and cultural heritage and tourism. 